\title{
A sea pen field in shallow water in the Amakusa Islands, southern Japan
}

\author{
Yuka Kushida $^{1, *}$, Hiroki Kise ${ }^{1}$, Catherine S. McFadden ${ }^{2} \&$ James Davis Reimer $^{1,3}$ \\ ${ }^{1}$ Molecular Invertebrate Systematics and Ecology Laboratory, Graduate School of Engineering and Science, \\ University of the Ryukyus, 1 Senbaru, Nishihara, Okinawa 903-0213, Japan \\ ${ }^{2}$ Biology Department, Harvey Mudd College, 1250 N. Dartmouth Ave, Claremont, CA, 91711, USA \\ ${ }^{3}$ Tropical Biosphere Research Center, University of the Ryukyus, 1 Senbaru, Nishihara, Okinawa 903-0213, Japan
}

Received 9 April 2020; Accepted 20 May 2020 Responsible Editor: Kensuke Yanagi

doi: $10.3800 /$ pbr. 15.259

\begin{abstract}
Sea pens are ecologically important habitats for associated marine organisms, serving as ecosystem engineers in sandy or muddy seafloor environments. In such areas, sea pens can form habitats with high population densities known as "sea pen fields". However, the presence and importance of sea pen fields have not been well studied in shallow waters in East Asia. Here, we report a sea pen field of Virgularia sp. aff. gustaviana in the shallow waters of Ushibuka Marine Park, in the Amakusa Islands of southern Japan. The average colony numbers of the field across all depths $\left(7-20 \mathrm{~m}\right.$ ) was 10.3 colonies $/ \mathrm{m}^{2}$ (live colonies) to 13.6 colonies $/ \mathrm{m}^{2}$ (all: live + dead colonies + holes), and the area of the sea pen field was at least $\sim 50,000 \mathrm{~m}^{2}$. At a depth of $15 \mathrm{~m}$, the substratum consisted of sand and fallen leaves of terrestrial origin, and the highest sea pen density was observed (averages $=17.2$ live colonies $/ \mathrm{m}^{2},=25.8$ total (live + dead + holes) colonies $/ \mathrm{m}^{2}$ ). At a depth of $20 \mathrm{~m}$, the substratum consisted of broken shells and rocks and had the lowest density (live colonies: average $=0.8$ colonies $/ \mathrm{m}^{2}$, all: average $=1.0$ colonies $/ \mathrm{m}^{2}$ ). There were significant differences in colony number of Virgularia sp. aff. gustaviana between the "sand", "sand+leaves", and "broken shells/rocks" substrates. We hypothesize that the strength of the water currents caused by local geographic features and tidal movements produce suitable sedimentation and habitat for this species of sea pen. Therefore, we suggest that preserving the natural coastline is crucial to protect this and other sea pen fields in shallow waters and their benthic marine communities.
\end{abstract}

Key words: Octocorallia, Pennatulacea, quadrats, Ushibuka Marine Park, Virgularia

\section{Introduction}

Octocorallia (Cnidaria: Anthozoa) consists of three orders: Alcyonacea, Helioporacea, and Pennatulacea (Fabricius \& Alderslade 2001). Sea pens, which belong to Pennatulacea, are usually seen on sandy and/or muddy seafloors from shallow to deep waters. They are morphologically specialized with a unique primary polyp, the oozooid. The oozooid has two main parts: the rachis and peduncle. The rachis produces secondary polyps such as autozooids, which have tentacles and are used for feeding and reproduction, and siphonozooids, which lack or have reduced tentacles that aid in water circulation. Addition-

\footnotetext{
*Corresponding author: Yuka Kushida; E-mail,kskrg.38@gmail.com
}

ally, some sea pens have other polyps, such as mesozooids or acrozooids (Williams 2011; Williams et al. 2012). The peduncle has well-developed muscles and is used to anchor the body in sandy and/or muddy places (Fabricius \& Alderslade 2001; Williams 2011; Lau et al. 2019).

Members of Octocorallia have important roles in various marine benthic communities around the world (McFadden et al. 2010). Sea pens can form habitats with exclusive and high densities known as "sea pen fields" (Kenchington et al. 2014). The Marine Habitat Classification for Britain and Ireland noted sea pens as the most conspicuous taxa among epibenthic species (Greathead et al. 2007). As sea pens form three-dimensional structures in flat places such as sandy and/or muddy bottoms, they have important roles in their ecosystems. For example, they can form habitats for other associated marine organisms such 
as sea anemones, crustaceans (Porcellanella spp., shrimps, barnacles, and copepods), crinoids, mollusks, and polychaetes (Sankarankutty 1961; Stevens \& Connolly 2003; Uyeno et al. 2016; Schejter et al. 2018). In deeper water, sea pens play an important role as fish larvae nurseries, which are relevant for commercially important species (Bailon et al. 2012). Moreover, the three-dimensional structures of sea pens can change water currents near the bottom. These changes in current can help maintain specific conditions in benthic environments, such as nutrient and organic matter levels and plankton concentrations (Tissot et al. 2006). Thus, similar to gorgonians and sponges, sea pens can be considered ecosystem engineers (Kenchington et al. 2014). Most sea pen fields have been reported from deeper waters $(60-2500 \mathrm{~m})$ via trawls or Remotely Operated Vehicles (ROVs) (Langton et al. 1990; Tissot et al. 2006; Bailon et al. 2012; Kenchington et al. 2014; Ruiz-Pico et al. 2017; Chimienti et al. 2019).

Although sea pens play important roles in benthic ecosystems, basic information on their diversity and ecology is still lacking for shallow waters (Kushida \& Reimer 2019). This study reports a sea pen field from the shallow waters of Ushibuka Marine Park, Amakusa Islands, Kumamoto, southern Japan, and provides ecological information.

\section{Materials and Methods}

\section{Location and in situ surveys}

The sea pen field (Fig. 1) is located within Ushibuka Marine Park, Amakusa Islands, Kumamoto, southern Japan $\left(32^{\circ} 09^{\prime} 19.4^{\prime \prime} \mathrm{N}, 130^{\circ} 02^{\prime} 37.2^{\prime \prime} \mathrm{E}\right)$ (Fig. 2). For this study, a preliminary survey was conducted on September 12, 2017, followed by three scuba dives conducted on September 25, 2018, with all dives conducted during daytime. To estimate the size of the sea pen field, we measured the length of the edge of the field and the angles of the corners using a tape measure and compass. To estimate the density of sea pens, we randomly placed $1 \times 1 \mathrm{~m}^{2}$ quadrats at $7,10,15$, and $20 \mathrm{~m}$ $(n=10-13$ quadrats per depth). Four digital images of approximately $50 \times 50 \mathrm{~cm}^{2}$ each were taken from each quadrat and subsequently analyzed.

\section{Species identification}

Specimens $(n=3)$ were collected during the preliminary survey on September 12, 2017 (specimen numbers YK210, YK211, and YK212) and were identified as belonging to the genus Virgularia Lamarck, 1816. Virgularia species have an axis throughout their length, small or thin polyp leaves upon which autozooids are aligned at the edge, a slender peduncle (Williams 1995; Imahara et al. 2014), and no sclerites in their polyp leaves. Virgularia species are circumglobally distributed, and have been reported at depths of $0-1100 \mathrm{~m}$ on sandy and muddy bottoms (Williams 1995, 2011). There have been a few reports related

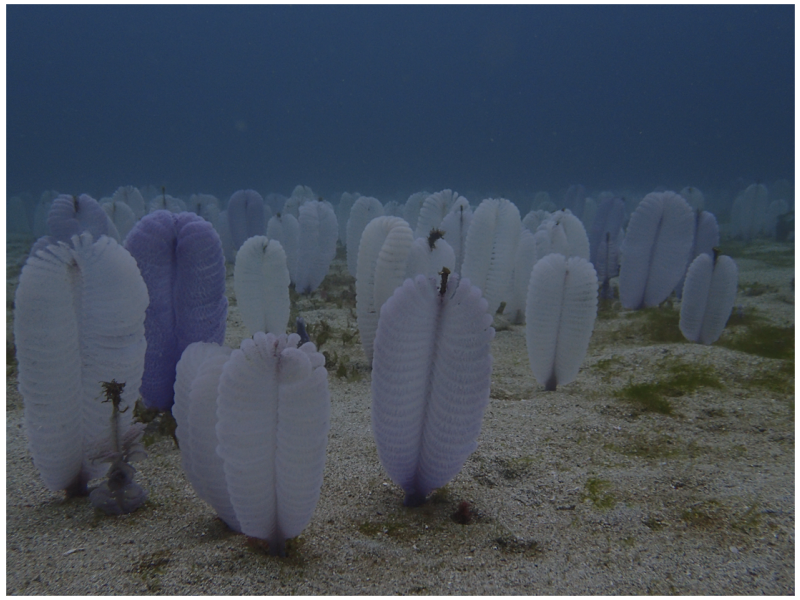

Fig. 1. In situ image of the sea pen field of Virgularia sp. aff. gustaviana at Ushibuka Marine Park (image 7-10 m in depth).

to the behavioral circadian rhythm of Virgularia species, such as examination of their withdrawing and movement (e.g., Soong 2005; Imahara \& Ogawa 2006; Ambroso et al. 2013). In particular, Virgularia juncea (Pallas, 1766) is well studied, being zooxanthellate and having a daily rhythmic withdrawal behavior (Soong 2005; Imahara \& Ogawa 2006).

The examined Virgularia specimens were identified as Virgularia sp. aff. gustaviana (Herklots, 1863). Virgularia gustaviana has a thick axis throughout its body, relatively large and fan-shaped polyp leaves, and numerous (50-200) autozooids on each polyp leaf. In this species, siphonozooids form rows between the polyp leaves and exist on the dorsal side of the rachis in great numbers (Herklots 1863; Kölliker 1870; Kükenthal 1915; Williams 1990; Imahara et al. 2014). However, there were some differences in the numbers of autozooids and body-color between previous descriptions of Virgularia gustaviana (e.g., Herklots 1863; Kölliker 1870; Kükenthal 1915; Williams 1990; Imahara et al. 2014). Additional taxonomic research (Kushida et al. unpublished data) considers Virgularia gustaviana to include cryptic species. Therefore, in this study, we treated the observed sea pens as Virgularia sp. aff. gustaviana.

\section{Image analyses}

After the field surveys, we counted the total number of sea pens (two categories: live and dead) in each quadrat. Dead sea pens were classified as lying flat on the seafloor and having a bare axis devoid of tissue. Although we observed a few other sea pen species during the course of the survey, only Virgularia sp. aff. gustaviana colonies were included within the quadrats. We also observed small holes (Fig. 3) in some quadrats, and these were judged to contain withdrawn sea pens via diving observation. Thus, we also counted the number of holes to obtain a potential maximum density of sea pens present at the site.

We categorized the substrate within each quadrat as "sand" (sand without any remarkable terrestrial-origin fall- 


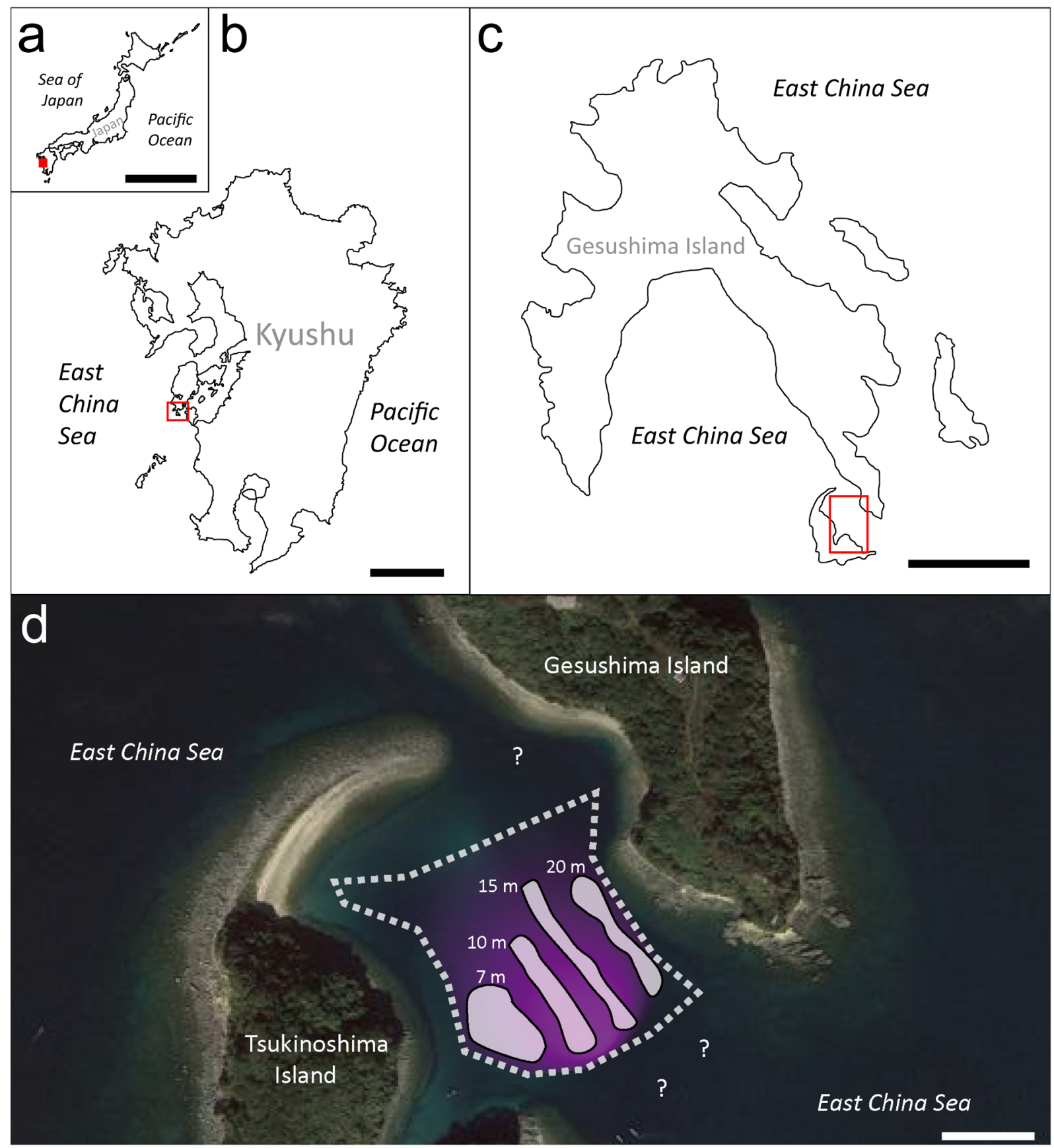

Fig. 2. Location of the sea pen field in Ushibuka Marine Park, Amakusa Islands, Kumamoto, southern Japan. a: map of Japan. Scale $=1000 \mathrm{~km}$. b: map of Kyushu. Scale $=60 \mathrm{~km}$. c: map of Gesushima Island, Kumamoto, southern Japan. Scale $=1 \mathrm{~km}$. a-c: red boxes indicate the approximate location of Ushibuka Marine Park. d: map of the sea pen field (contained within dashed white lines, with rough density in purple) in Ushibuka Marine Park. The light purple area indicates approximate quadrat locations. Scale $=100 \mathrm{~m}$. Map image from Google Earth.

en leaves or tree branches), "sand+leaves" (sand with noticeable fallen leaves and/or tree branches), "broken shells," or "rocks," (including those with dead barnacles) (Fig. 3). For statistical analyses, we treated "broken shells" and "rocks" as one category as there was only one quadrat with "rocks," the distance between "rocks" and "broken shells" was short (within $10 \mathrm{~m}$ ), and the depth was the same (20 m) for both.
The data, including numbers of Virgularia sp. aff. gustaviana (live only, live + dead + holes), depths, and substrate type, were subjected to statistical analyses in $\mathrm{R}$ studio v.1.2.5019 (R Studio Team 2015). To examine the distribution of Virgularia sp. aff. gustaviana, a Shapiro-Wilk normality test was conducted. Subsequently, Kruskal-Wallis rank-sum tests were conducted to examine if there were significant differences in numbers by depth and substra- 

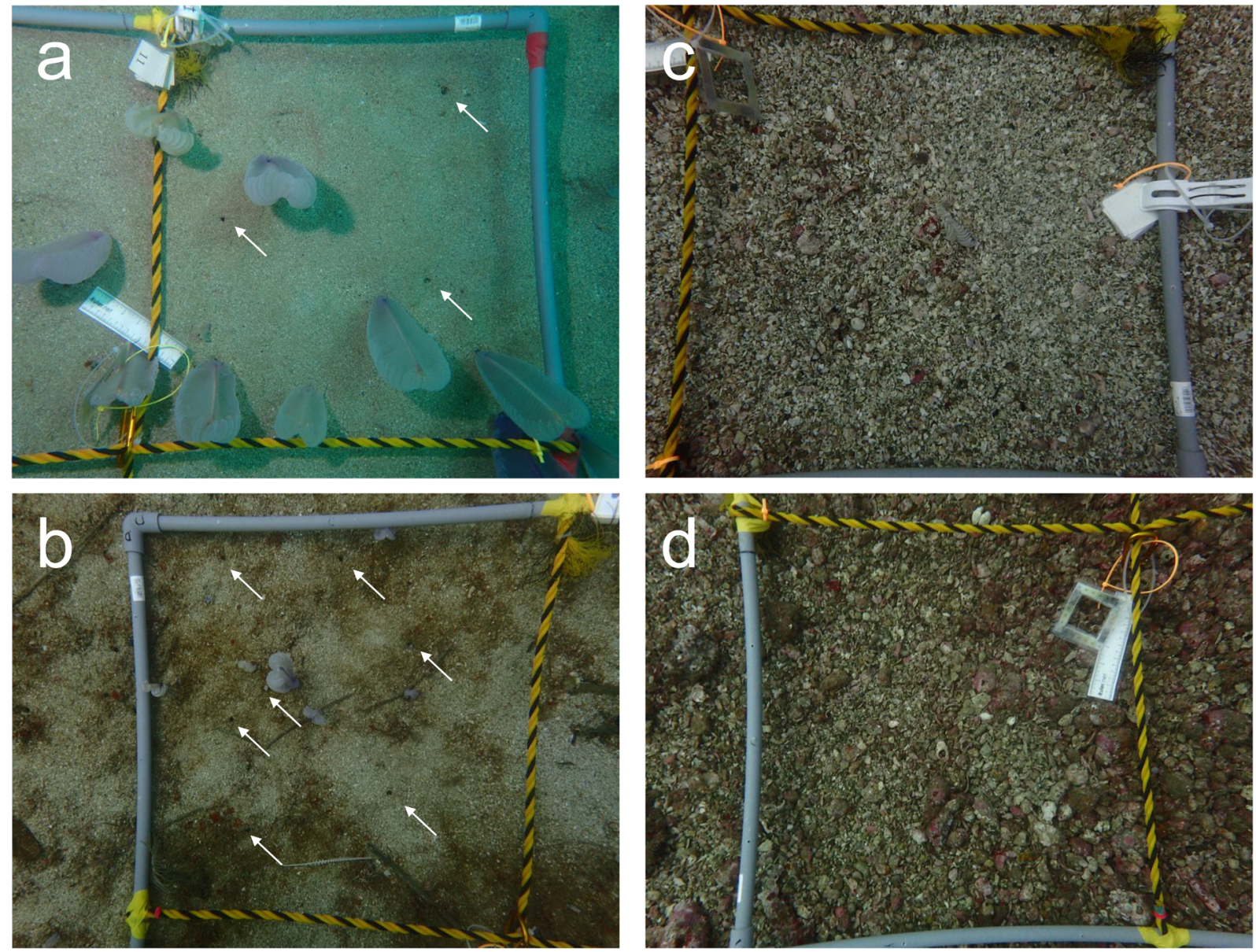

Fig. 3. Images of substrate categories. White arrows indicate holes judged to contain withdrawn Virgularia sp. aff. gustaviana. a: "sand" = sand with no remarkable leaves or tree branches. b: "sand+leaves" =sand including remarkable leaves and/or tree branches. c: "broken shells" = consisting mainly of broken shells. d: "rocks" = consisting of rocks and/or barnacles.

tum type. Dunn's tests (Dunn 1964) were conducted to examine the pairwise comparisons between number-depth and number-substratum. A Bonferroni correction was used to adjust the $p$-values. We treated $<0.05 p$-values as significant.

\section{Results}

The external edge of the Ushibuka sea pen field was estimated to be just over $1 \mathrm{~km}$ in length $(1012 \mathrm{~m}$; white dashed line in Fig. 2-d), although the edges on the northern and southern sides could not be exactly ascertained (question marks in Fig. 2-d) due to deeper depths (south side) or strong currents (north side) making scuba dives dangerous. Thus, the area of the sea pen field was estimated to be at least $49,521 \mathrm{~m}^{2}$. However, due to the lack of clearly determined southern and northern edges, it is likely slightly larger.

Inside the sea pen field, Virgularia sp. aff. gustaviana was exclusively dominant. We counted a total of 464 colonies (45 quadrats; average 10.3 colonies/quadrat). The number of living colonies found at each depth ranged from

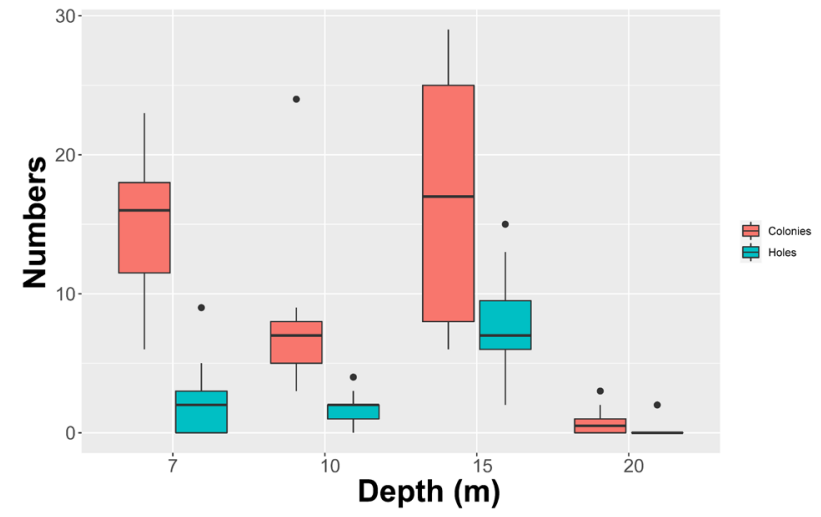

Fig. 4. Numbers of Virgularia sp. aff. gustaviana live colonies (red color) and holes (blue-green color) per quadrat at each depth (m).

eight to 189 colonies (from 0.8 to $17.2 / \mathrm{m}^{2}$ ). The $15 \mathrm{~m}$ depth had the highest density of colonies, while $20 \mathrm{~m}$ had the lowest density (Table 1, Fig. 4). At $7 \mathrm{~m}$, the maximum number of colonies in one quadrat was 23 colonies, while the minimum was six colonies. At $10 \mathrm{~m}$, the maximum was 24 colonies and the minimum was three colonies; at 
Table 1. Number of Virgularia sp. aff. gustaviana by depth. The area of each quadrat is $1 \times 1 \mathrm{~m}^{2}$. Estimated colonies includes the number of live + dead colonies + holes.

\begin{tabular}{|c|c|c|c|c|c|}
\hline Depth (no. qudrats) & $7 \mathrm{~m}(\mathrm{n}=11)$ & $10 m(n=13)$ & $15 \mathrm{~m}(\mathrm{n}=11)$ & $20 \mathrm{~m}(\mathrm{n}=10)$ & Total $(n=45)$ \\
\hline No. living colonies & 165 & 102 & 189 & 8 & 464 \\
\hline Avg. living colonies/quadrat & 15.0 & 7.8 & 17.2 & 0.8 & 10.3 \\
\hline No. holes & 26 & 23 & 89 & 2 & 140 \\
\hline Avg. holes/quadrat & 2.4 & 1.8 & 8.1 & 0.2 & 3.1 \\
\hline No. dead colonies & 2 & 0 & 6 & 0 & 8 \\
\hline Avg. dead colonies & 0.2 & 0.0 & 0.5 & 0.0 & 0.2 \\
\hline No. estimated colonies & 193 & 125 & 284 & 10 & 612 \\
\hline Avg. estimated colonies/quadrat & 17.5 & 9.6 & 25.8 & 1.0 & 13.6 \\
\hline
\end{tabular}

Table 2. Number of Virgularia sp. aff. gustaviana by substratum. The area of each quadrat is $1 \times 1 \mathrm{~m}^{2}$. Estimated colonies includes the number of live + dead colonies + holes.

\begin{tabular}{|c|c|c|c|c|c|}
\hline Substrate (no. quadrats) & Sand $(n=22)$ & $\begin{array}{l}\text { Sand+leaves } \\
(n=13)\end{array}$ & $\begin{array}{l}\text { Broken shells } \\
\qquad(n=9)\end{array}$ & Rocks $(n=1)$ & Total $(n=45)$ \\
\hline No. living colonies & 228 & 228 & 8 & 0 & 464 \\
\hline Avg. living colonies/quadrat & 10.4 & 17.5 & 0.9 & 0.0 & 10.3 \\
\hline No. holes & 43 & 95 & 2 & 0 & 140 \\
\hline Avg. holes/quadrat & 2.0 & 7.3 & 0.2 & 0.0 & 3.1 \\
\hline No. dead colonies & 0 & 8 & 0 & 0 & 8 \\
\hline Avg. dead colonies & 0.0 & 0.6 & 0.0 & 0.0 & 0.2 \\
\hline No. estimated colonies & 271 & 331 & 10 & 0 & 612 \\
\hline Avg. estimated colonies/quadrat & 12.3 & 25.5 & 1.1 & 0.0 & 13.6 \\
\hline
\end{tabular}

$15 \mathrm{~m}$, the maximum was 29 colonies and the minimum was six colonies; and at $20 \mathrm{~m}$, the maximum was three colonies and the minimum zero colonies. We observed two dead sea pens at $7 \mathrm{~m}$, zero at $10 \mathrm{~m}$, six at $15 \mathrm{~m}$, and zero at $20 \mathrm{~m}$ (Table 1). We also counted a total of 140 holes (45 quadrats; average 3.1 holes/quadrats). The number of holes found at each depth ranged from two to 89 holes (from 0.2 to $8.1 / \mathrm{m}^{2}$ ), with the fewest found at $20 \mathrm{~m}$ and the most at $15 \mathrm{~m}$ (Table 1, Fig. 4).

We counted the estimated total number of sea pens (live + dead + holes), and there were a total of 612 colonies (45 quadrats; average 13.6 colonies/quadrat). The number of estimated total sea pens (live + dead + holes) found at each depth ranged from 10 to 284 colonies (from 1.0 to $25.8 / \mathrm{m}^{2}$ ), with the fewest found at $20 \mathrm{~m}$ and the most at $15 \mathrm{~m}$ (Table 1, Fig. 4).

Regarding the seafloor categories, "sand" was observed at $7 \mathrm{~m}$ (9/11 quadrats) and $10 \mathrm{~m}$ (13/13 quadrats), "sand+leaves" was observed at $7 \mathrm{~m}$ (2/11 quadrats) and $15 \mathrm{~m}$ (11/11 quadrats), "broken shells" was observed at $20 \mathrm{~m}$ (9/10 quadrats), and "rocks" was observed at $20 \mathrm{~m}$ (1/10 quadrats). The number of living sea pens found at each substrate category ranged from 0 to 228 colonies (from 0.0 to 17.5 colonies $/ \mathrm{m}^{2}$ ), with the lowest density found in "rocks" and the highest density in "sand+leaves" (Table 2, Fig. 5). The number of living colonies in one quadrat was 3-24 colonies for "sand," 6-29 colonies for "sand+leaves," and 0-3 colonies for "broken shells." Ad-

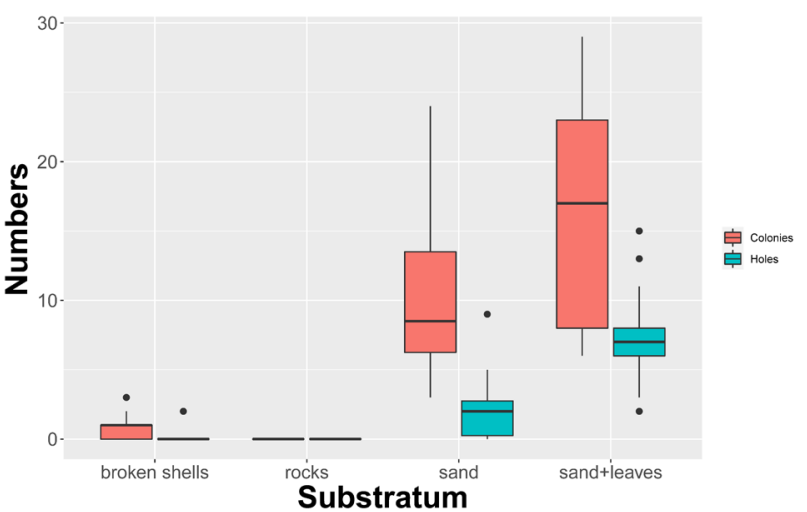

Fig. 5. Numbers of Virgularia sp. aff. gustaviana live colonies (red color) and holes (blue-green color) per quadrat for each substrate type.

ditionally, there were eight dead sea pens in the category "sand+leaves," and zero in "sand," "broken shells," and "rocks" (Table 2). The numbers of the holes found at each substrate category ranged from 0 to 95 ( 0.0 to 7.3 colonies $/ \mathrm{m}^{2}$ ), with the fewest found in "rocks" and the most in "sand+leaves" (Table 2, Fig. 5). The number of estimated total sea pens (live+dead+holes) found at each substrate category ranged from 0 to 331 colonies (from 0.0 to $25.5 / \mathrm{m}^{2}$ ), with the fewest found in "rocks" and the most in "sand+leaves" (Table 2, Fig. 5).

As the Shapiro-Wilk normality test results suggested 
that the histograms of sea pen numbers (both live and live+dead+holes) fitted a non-parametric distribution $(p<0.05)$, we conducted non-parametric statistical analyses. The Kruskal-Wallis rank-sum test showed significant differences in number by depth (only live: $p=1.389 \mathrm{e}^{-6}$, live + dead + holes: $p=1.542 \mathrm{e}^{-7}$ ) and number by substrate (only live: $p=1.75 \mathrm{e}^{-6}$, live + dead + holes: $p=1.158 \mathrm{e}^{-7}$ ). The Dunn's test of live colony numbers only by depth showed significant differences between 7 and $20 \mathrm{~m}\left(p=1.97976 \mathrm{e}^{-5}\right.$; p.adj $), 10$ and $20 \mathrm{~m}\left(p=4.545913 \mathrm{e}^{-2}\right.$; p.adj), and 15 and $20 \mathrm{~m}\left(p=1.060973 \mathrm{e}^{-5}\right.$; p.adj). In addition, Dunn's test of only live number by substrate showed significant differences between "broken shells/rocks" and "sand" ( $p=3.804554 \mathrm{e}^{-4} ;$ p.adj), "broken shells/rocks" and "sand+leaves" ( $p=1.146086 \mathrm{e}^{-6} ; \mathrm{p}$.adj). The Dunn's test of number of live+dead+holes by depth showed significant differences between 7 and $20 \mathrm{~m}\left(p=1.235668 \mathrm{e}^{-4}\right.$; p.adj), 10 and $15 \mathrm{~m}\left(p=4.181767 \mathrm{e}^{-3}\right.$; p.adj), 15 and $20 \mathrm{~m}$ $\left(p=2.790976 \mathrm{e}^{-7} ; \mathrm{p} . \mathrm{adj}\right)$. Also, Dunn's test of only live number by substrate showed significant differences between "broken shells/rocks" and "sand" ( $p=1.787368 \mathrm{e}^{-3}$; p.adj), "broken shells/rocks" and "sand+leaves" ( $p=4.795302 \mathrm{e}^{-8}$; p.adj), "sand" and "sand+leaves" ( $p=6.843888 \mathrm{e}^{-3}$; p.adj).

Additionally, we observed other benthic species amongst the sea pens, including crinoids, hydroids, and juvenile fish of the order Tetraodontiformes (Fig. 6-a, b, c). We also observed an Armina semperi (Bergh, 1861) nudibranch, a known predator of sea pens (Birkeland 1974; Fig. 6-d). Finally, we noted Virgularia sp. aff. gustaviana colonies with flourishing algae on top of their axes. The flourishing algae suggested that such sea pens were damaged (Fig. 6 -e).

\section{Discussion}

In this study, we report a sea pen field in the shallow waters of Ushibuka Marine Park, Amakusa Islands, Kumamoto, southern Japan. Ushibuka Marine Park was one of the first marine parks designated in Japan (designated in 1970; Ministry of the Environment Government of Japan 2006). The park is a tourist attraction, with popular glassbottom boat and scuba diving tours, due to an abundance of scleractinian corals, octocorals such as soft corals and sea fans, and tropical fishes. The importance of this site has been previously recognized, and efforts to protect the scleractinian corals in the park from Acanthaster Gervais, 1841 crown-of-thorns sea stars and Morula spinosa (H. Adams \& A. Adams, 1853) mollusks have been conducted in the past (Ministry of the Environment Government of Japan 2006). Despite being widely known among domestic tourists, there have been no scientific reports or examinations of this sea pen field, which reflects the general lack of knowledge regarding the importance of shallow water sea pens.

In the current study, we observed an average density of sea pens of 10.3 colonies $/ \mathrm{m}^{2}$ and a maximum density of
29 colonies $/ \mathrm{m}^{2}$. When holes + dead sea pens were added to these numbers, we observed a maximum density of 39 colonies $/ \mathrm{m}^{2}$ ( 28 live colonies +11 holes +0 dead sea pens). In other surveys, Tissot et al. (2006) noted around 819 colonies/hectare $\left(0.08\right.$ colonies $\left./ \mathrm{m}^{2}\right)$ at a $157 \mathrm{~m}$ mean depth in California, whereas Langton et al. (1990) estimated the density of Pennatula aculeata Danielssen, 1860 of $0-8 / \mathrm{m}^{-2}$ at 266 locations in the cold waters of the Gulf of Maine, USA (at 119-351 m). In Canada's exclusive economic zone (EEZ) in the northwest Atlantic, trawl surveys at $2500 \mathrm{~m}$ showed areas with $\geq 1.4 \mathrm{~kg}$ of sea pens per $\mathrm{km}^{2}$ (Kenchington et al. 2014). Trawl surveys from the Bay of Biscay, Spain, at 70-500 m, also noted 23 colonies/haul (approximately 438 colonies $/ \mathrm{km}^{2}$ ) of Funiculina quadrangularis (Pallas, 1766), and nine colonies/haul (171 colonies $/ \mathrm{km}^{2}$ ) of Pennatula spp. (Ruiz-Pico et al. 2017). When compared to these deeper water sites, the densities observed at Ushibuka are much greater.

Based on our results, we hypothesize that the water currents present in the channel between Gesushima Island and Tsukinoshima Island (Fig. 2) help create suitable sedimentation and environments for Virgularia sp. aff. gustaviana. The results showed that the substrates were different by depth, with "sand" and "sand+leaves" being predominant at 7 and $10 \mathrm{~m}$ and $15 \mathrm{~m}$, respectively, and "broken shells/ rocks" being observed only at $20 \mathrm{~m}$. Virgularia sp. aff. gustaviana densities were highest at $15 \mathrm{~m}$, where leaves were deposited in large numbers. This suggests that this depth/location may represent a "sink" not only for fallen leaves but also for plankton, probably contributing to the observed high densities as sea pens are planktivorous. Furthermore, the differences in substrate could also depend on the strength of the water current at each depth. For example, when current strength is reduced, sedimentation shifts from non-cohesive sediments to cohesive muddy sediments (Sakamaki \& Nishimura 2007). In addition, water currents have been shown to help wash sediments on sea pens away, although sea pens have tolerance towards sedimentation (Best 1988; Torre et al. 2012).

Moreover, such locations may be comparatively easier for sea pen planula larvae to reach. Environments with sandy bottoms and organic components are thought to be suitable for the settlement and metamorphosis of sea pen planula larvae. In an experiment, Chia \& Crawford (1973) showed Ptilosarcus gurneyi (Gray, 1860) planula larvae in culture dishes settled to conduct metamorphosis seven days after fertilization when the sand particle size and organic components were at appropriate levels, while the absence of such conditions resulted in metamorphosis occurring after at least 30 days (Chia \& Crawford 1973). Thus, appropriate sizes of the particles (around 70-1000 $\mu \mathrm{m}$ ) and levels of organic components may be important factors for the formation of this and other sea pen fields. Such natural geographic traits could help create the appropriate currents and suitable sedimentation at Ushibuka Marine Park, which may allow this high-density Virgularia sp. aff. 


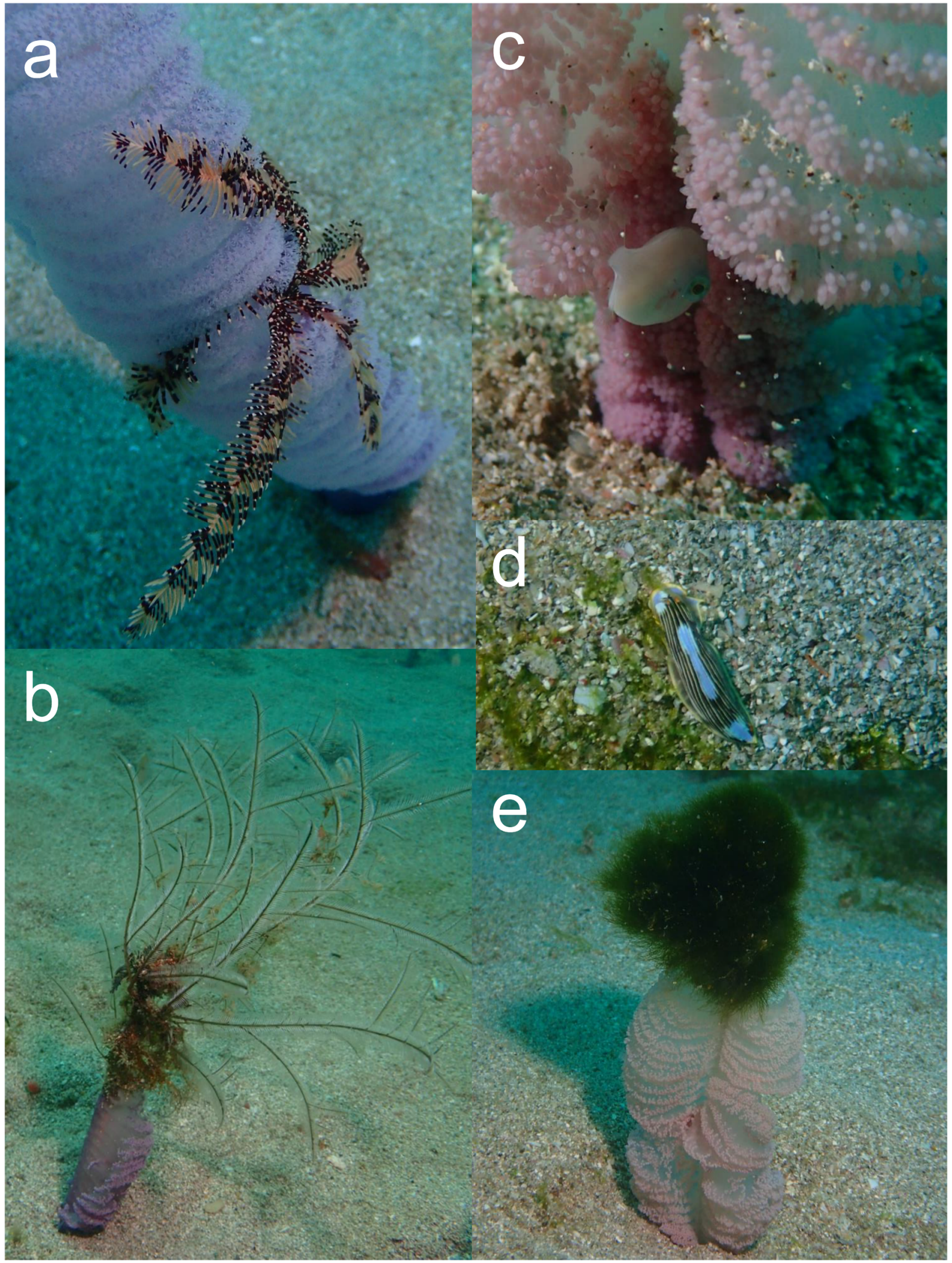

Fig. 6. Images of associated marine organisms of Virgularia sp. aff. gustaviana. a: crinoid, b: hydroids, c: juvenile Tetraodontiformes fish, d: nudibranch Armina semperi (Bergh, 1861), e: algae on top of the axis of Virgularia sp. aff. gustaviana. 
gustaviana sea pen field. As this park and sea pen field are known from the 1970s, it can be considered that this ecosystem is at least somewhat stable and does not represent a new occurrence.

In San Diego, California, USA, Davis et al. (1982) studied the effects of artificial structures and organisms in sandy bottom communities and noted that after establishing artificial reefs, the sea pen Stylatula elongata Verrill, 1864 completely disappeared within $30 \mathrm{~m}$ from the artificial reefs after three months, while numbers declined at distances of up to more than $100 \mathrm{~m}$ from the artificial reefs after 17 months. At the same time, polychaete Diopatra spp. numbers increased near the artificial reefs. These results suggest that artificial alterations of coastlines can negatively impact sea pen fields, and the Japanese coastline has been increasingly artificially armored over time (Sale et al. 2008; Masucci \& Reimer 2019). To conserve this sea pen field and other sea pen fields in shallow waters, we suggest that the preservation of the natural coastline is necessary to avoid alteration of currents in benthic marine environments.

The formation of sea pen fields may also be related to asexual reproduction. In the case of the mushroom scleractinian corals of the family Fungiidae Dana, 1846, species have the ability to form "mushroom coral gardens" via asexual budding or fragmentation (Hoeksema 2004; Hoeksema et al. 2019). In the order Pennatulacea, some species of Pteroeides Herklots, 1858 are known to have acrozooids that are thought to function in asexual reproduction such as budding (Williams et al. 2012). In shallow waters, Junceella spp. ellisellid gorgonians, which are phylogenetically close to sea pens, have a strategy of budding at the distal part of the colony for asexual reproduction (Williams et al. 2012). Virgularia species do not have acrozooids, and asexual reproduction strategies of sea pens, including Virgularia species, are still generally unknown. Future studies on the reproductive strategies of sea pens may help shed further light on the formation of sea pen fields.

During our surveys, we were able to observe marine organisms associated with sea pens, including crinoids, hydroids, and juvenile fish. Crinoids are known as suspension feeders (Baumiller et al. 2008), and they may be able to obtain more food from the water column via perching with their cirri and arms when perched on sea pens (Stevens \& Connolly 2003; Wilson 2005). Similarly, some hydroids form planktivorous benthic colonies that need specific substrates and have important roles in transferring the energy of small marine organisms to the benthic community from the water column (Gili et al. 1998; Cantero et al. 2013). As with crinoids, the sea pen's three-dimensional structure may improve the feeding efficiency of hydroids.

Similarly, juvenile marine species are known to utilize sea pens as shelters, as we also observed in this study. In Scotland, Nephrops spp. shrimp are an important marine product, and sea pens have been shown to harbor im- mature Nephrops (Greathead et al. 2007). Clippele et al. (2015) surveyed marine organisms associated with gorgonians and sea pens in cold waters of Norway (116-863 m) and noted that an understanding of the ecological importance of these associated marine organisms is needed to better manage the deep-sea fisheries industry. Fisheries are an important industry in Amakusa City (Shinohara 2007), and thus, this sea pen field may contribute to the support of the soft bottom marine community and fisheries in the region.

Although sea pen fields and their importance remain to be well recognized in Asia, studies in other regions have previously focused on this subject. In the northwest Atlantic, sea pen fields are designated as vulnerable marine ecosystems (VMEs) to prevent adverse effects from destructive bottom fisheries, and are thus protected by the Northwest Atlantic Fisheries Organization (NAFO). In Canada, sea pen fields are designated as ecological or biological significant areas (EBSAs) and significant benthic areas (Kenchington 2014; Murillo et al. 2018). Additionally, coral gardens (aggregations of gorgonians and sea pens) are classified as "Threatened and/or Declining Habitat" by the Oslo and Paris Conventions (OSPAR) in the northeast Atlantic (OSPAR, 2004; Greathead et al. 2007). As sea pen fields provide three-dimensional habitats in sandy or muddy areas and help maintain aspects of the benthic environment, such as nutrient and organic matter levels (e.g., Chimienti et al. 2019; Tissot et al. 2006), further research is clearly needed to better ascertain the ecological roles of sea pen fields.

Although marine parks are often created to help conserve important marine organisms such as scleractinian corals, gorgonians, and soft corals (e.g., Ministry of the Environment Government of Japan 2006), and the Ushibuka sea pen field is within the oldest marine park in Japan, until now the importance of sea pen fields has not been well recognized in this region. As basic studies on sea pen diversity and ecology are still lacking (Kushida \& Reimer 2019; Kushida et al. 2020), there is still a clear need to accumulate more basic sea pen information and data.

\section{Acknowledgements}

We thank Hikaru Tomikawa and Kimiko Tomikawa from Tomikawa Diving Shop (Ushibuka) for their help with field surveys in 2017 and 2018. We also thank Dr. Shiori Kunihiro (Okinawa Churashima Foundation) and Minaho Fukagawa (Ushibuka diving club) for help with the preliminary survey in 2017, Dr. Wee Hin Boo for advice on statistical analyses, and Ifue Fukuchi (both University of the Ryukyus) for advice on the identification of juvenile fish. The preliminary survey in 2017 was supported by an Individual Research Grant from the Research Institute of Marine Invertebrates [grant number: "Ko"-20]. Surveys in 2018 were supported by an ORCHIDS grant from the University of the Ryukyus to CSM and JDR. Comments from 
two anonymous reviewers and editor Kensuke Yanagi improved this manuscript.

\section{References}

Ambroso S, Dominguez-Carrió C, Grinyó J, López-González PJ, Gili JM, Purroy A, Requena S, Madurell T (2013) In situ observations on withdrawal behaviour of the sea pen Virgularia mirabilis. Mar Biodivers 43: 257-258.

Baillon S, Hamel JF, Wareham VE, Mercier A (2012) Deep cold water corals as nurseries for fish larvae. Front Ecol Environ 10: 351-356.

Baumiller TK (2008) Crinoid ecological morphology. Annu Rev Earth P1 Sc 36: 221-249.

Best BA (1988) Passive suspension feeding in a sea pen: effects of ambient flow on volume flow rate and filtering efficiency. Biol Bull 175: 332-342.

Birkeland C (1974) Interactions between a sea pen and seven of its predators. Ecol Monogr 44: 211-232.

Cantero ÁLP, Boero F, Piraino S. (2013) Shallow-water benthic hydroids from Tethys Bay (Terra Nova Bay, Ross Sea, Antarctica). Polar Biol 36: 731-753.

Chia FS, Crawford BJ. (1973) Some observations on gametogenesis, larval development and substratum selection of the sea pen Ptilosarcus guerneyi. Mar Biol 23: 73-82.

Chimienti G, Di Nisio A, Lanzolla AM, Andria G, Tursi A, Mastrototaro F (2019) Towards non-invasive methods to assess population structure and biomass in vulnerable sea pen fields. Sensors 19: 2255.

De Clippele LH, Buhl-Mortensen P, Buhl-Mortensen L (2015) Fauna associated with cold water gorgonians and sea pens. Cont Shelf Res 105: 6778.

Davis N, VanBlaricom GR, Dayton PK (1982) Man-made structures on marine sediments: effects on adjacent benthic communities. Mar Biol 70: 295-303.

Dunn OJ (1964) Multiple comparisons using rank sums. Technometrics 6: 241-252.

Fabricius KK, Alderslade PP (2001) Soft corals and sea fans: a comprehensive guide to the tropical shallow water genera of the central-west Pacific, the Indian Ocean and the Red Sea. Australian Institute of Marine Science (AIMS), Townsville, Queensland, pp. 6-8.

Gili JM, Alvà V, Coma R, Orejas C, Pagès F, Ribes M, Zabala M, Arntz W, Bouillon J, Boero F, Hughes RG (1998) The impact of small benthic passive suspension feeders in shallow marine ecosystems: the hydroids as an example. Zool Verh 323: 99-105.

Greathead CF, Donnan DW, Mair JM, Saunders GR (2007) The sea pens Virgularia mirabilis, Pennatula phosphorea and $\mathrm{Fu}$ niculina quadrangularis: distribution and conservation issues in Scottish waters. J Mar Biol Assoc UK 87: 1095-1103.

Herklots JA (1863) Descriptions de deux expèces nouvelles de pennatulidés des Mers de la Chine. Ned Tijdschr Dierk 1: 31 34.

Hoeksema BW (2004) Impact of budding on free-living corals at East Kalimantan, Indonesia. Coral Reefs 23: 492 pp.

Hoeksema BW, Sellanes J, Easton EE (2019) A high-latitude, mesophotic Cycloseris field at $85 \mathrm{~m}$ depth off Rapa Nui (Easter Island). Bull Mar Sci 95: 101-102.

Imahara Y, Ogawa K (2006) Rediscovery of Virgularia juncea (Octocorallia, Pennatulacea) from a tidal marsh in Okinawa, with a short note on its peculiar behavior. Proc 10th Int Coral Reef Sym: 9-13.

Imahara Y, Iwase F, Namikawa H (2014) The octocorals of Sagami Bay. Tokai University Press, Hadano, Kanagawa.

Kenchington E, Murillo FJ, Lirette C, Sacau M, Koen-Alonso M, Kenny A, Ollerhead N, Wareham V, Beazley L (2014) Kernel density surface modelling as a means to identify significant concentrations of vulnerable marine ecosystem indicators. PLoS ONE 9: e109365.

Kölliker RA von (1870) Anatomisch-Systematische Beschreibung der Alcyonararien. Erste Abtheilung. Die Pennatuliden. Abh Senckenb Naturforsch Ges 7: 487-602.

Kükenthal W (1915) Pennatularia. Das Tierreich. 43: 1-132. Verlag von R. Friedländer und Sohn, Berlin.

Kushida Y, Reimer JD (2019) Molecular phylogeny and diversity of sea pens (Cnidaria: Octocorallia: Pennatulacea) with a focus on shallow water species of the northwestern Pacific Ocean. Mol Phylogenet Evol 131: 233-244.

Kushida Y, Higashiji T, Reimer JD (2020) First observation of mole-like burrowing behavior observed in a sea pen. Mar Biodivers 50: 29. doi: 10.1007/s12526-020-01054-y

Langton RW, Langton EW, Theroux RB, Uzmann JR (1990) Distribution, behavior and abundance of sea pens, Pennatula aculeata, in the Gulf of Maine. Mar Biol 107: 463-469.

Lau YW, Poliseno A, Kushida Y, Quéré G, Reimer JD (2019) The classification, diversity and ecology of shallow water octocorals. In: Reference Module in Earth Systems and Environmental Sciences, Elsevier, Amsterdam, Noord-Holland, doi: 10.1016/B978-0-12-409548-9.12109-8

Masucci GD, Reimer JD (2019) Expanding walls and shrinking beaches: loss of natural coastline in Okinawa Island, Japan. Peer J 7: e7520.

McFadden CS, Sánchez JA, France SC (2010) Molecular phylogenetic insights into the evolution of Octocorallia: a review. Integr Comp Biol 50: 389-410.

Ministry of the Environment Government of Japan (2006) Unzen Amakusa National Park, Amakusa Regional Management Plan, 1-29. (in Japanese)

Murillo FJ, MacDonald BW, Kenchington E, Campana SE, Sainte-Marie B, Sacau M (2018) Morphometry and growth of sea pen species from dense habitats in the Gulf of St. Lawrence, eastern Canada. Mar Biol Res 14: 366-382.

OSPAR (2004) Descriptions of habitats on the initial OSPAR list of threatened and/or declining species and habitats. OSPAR Convention for the Protection of the Marine Environment of the North-East Atlantic. OSPAR, London 2004-7, 7 pp.

RStudio Team (2015) RStudio: Integrated Development for R. RStudio, Inc., Boston, MA URL http://www.rstudio.com/ on 2020-03-31

Ruiz-Pico S, Serrano A, Punzón A, Altuna Á, Fernández-Zapico O, Velasco F (2017) Sea pen (Pennatulacea) aggregations on the northern Spanish shelf: distribution and faunal assemblages. Sci Mar 81: 413-423.

Sakamaki T, Nishimura O (2007) Physical control of sediment 
carbon content in an estuarine tidal flat system (Nanakita River, Japan): a mechanistic case study. Estuar Coast Shelf Sci 73: 781-791.

Sale PF, Butler MJ, Hooten AJ, Kritzer JP, Lindeman KC, Sadovy YJ, Steneck RS, Van Lavieren H (2008) Stemming decline of the coastal ocean: rethinking environmental management. United Nations University-INWEH, Hamilton, Ontario.

Sankarankutty C (1961) On the porcellanid crab, Porcellanella triloba White (Crustacea-Anomura), a commensal on sea pen with remarks on allied species. Mar Biol Ass India 3: 96-100.

Schejter L, Acuña FH, Garese A, Cordeiro R, Pérez C (2018) Sea pens (Cnidaria: Pennatulacea) from Argentine waters: new distributional records and first report of associated sea anemones. Pan-Am J Aquat Sci 13: 292-301.

Soong K (2005) Reproduction and colony integration of the sea pen Virgularia juncea. Mar Biol 146: 1103-1109.

Stevens T, Connolly RM (2003) Shallow water crinoids are on soft sediments too: evidence from a video survey of a subtropical estuary. Bull Mar Sci 73: 593-604.

Shinohara S (2007) Fishing-industries' areas of the coast in Japan by the distribution of main places of fisheries' headquarters and fish-landing. Mem Facult Edu Human Stud Akita Univ 62: 37-47. (in Japanese)

Tissot BN, Yoklavich MM, Love MS, York K, Amend M (2006) Benthic invertebrates that form habitat on deep banks off southern California, with special reference to deep sea coral. Fish Bull 104: 167-181.

Torre L, Servetto N, Eöry ML, Momo F, Tatián M, Abele D, Sahade R (2012) Respiratory responses of three Antarctic ascidians and a sea pen to increased sediment concentrations. Polar Biol 35: 1743-1748.

Uyeno H, Jimi N, Uyeno D (2016) Marine invertebrates associated with the sea pen Cavernulina sp. (Octocorallia: Pennatulacea: Veretillidae) in the Oshima Strait, Amami Island, southern Japan. Nature of Kagoshima 42: 487-491. (in Japanese)

Williams GC (1990) The Pennatulacea of southern Africa (Coelenterata, Anthozoa). Ann S Afr Mus 99: 31-119.

Williams GC (1995) Living genera of sea pens (Coelenterata: Octocorallia: Pennatulacea): illustrated key and synopses. Zool J Linn Soc 113: 93-140.

Williams GC (2011) The global diversity of sea pens (Cnidaria: Octocorallia: Pennatulacea). PLoS ONE 6: e22747.

Williams GC, Hoeksema BW, van Ofwegen LP (2012) A fifth morphological polyp in pennatulacean octocorals, with a review of polyp polymorphism in the genera Pennatula and Pteroeides (Anthozoa: Pennatulidae). Zool Stud 51: 10061017.

Wilson NG (2005) Site fidelity of mariametrid crinoids (Echinodermata: Crinoidea) in southeast Sulawesi, Indonesia. Coral Reefs 24: 99-101. 